\title{
Patterns and sources of variation in flowering, seed supply and seedling recruitment in surfgrass Phyllospadix torreyi
}

\author{
Daniel C. Reed ${ }^{1, *}$, Sally J. Holbrook ${ }^{1,2}$, Carol A. Blanchette ${ }^{1}$, Suzanne Worcester $^{3}$ \\ ${ }^{1}$ Marine Science Institute, University of California, Santa Barbara, California 93106, USA \\ ${ }^{2}$ Department of Ecology, Evolution, and Marine Biology, University of California, Santa Barbara, California 93106, USA \\ ${ }^{3}$ Division of Science and Environmental Policy, California State University, Monterey Bay, 100 Campus Center, Seaside, \\ California 93955, USA
}

\begin{abstract}
Knowledge of patterns and sources of variation in adult reproduction and juvenile recruitment is essential for understanding the dynamics of populations and their capacity to recover from disturbances. In-depth knowledge of this kind is lacking for many species of seagrass. Here we examined the degree to which temporal and spatial variation in seedling density in the surfgrass Phyllospadix torreyi was explained by the local production and deposition of seeds. We did this by measuring floral density, seed production, seed supply and seedling recruitment at 5 sites near Santa Barbara, California, USA, over a $4 \mathrm{yr}$ period. We found that the local density of dehisced female spadices explained nearly $41 \%$ of the variation in the number of seeds caught in seed traps. Large seed crops were common in the absence of nearby males and noticeable numbers of seeds were periodically caught in traps when female flowers were locally rare or absent, suggesting that pollen and seed dispersal occasionally occurred over distances greater than the scale of our study sites (i.e. $>50 \mathrm{~m}$ ). Overall, the summer densities of female spadices at a site explained $>60 \%$ of the variation in the density of seedlings that recruited to the site the following winter. Deviations from positive associations among surfgrass flowers, seeds and seedlings appeared to reflect interannual variability in environmental conditions. Most notable was the coincidence of universally low fruit production and seedling recruitment during the 1997-1998 El Niño event. Seedling density varied independently of rates of seed deposition when all years were examined, but was highly dependent on rates of seed supply when the seedling data from the 1998 El Niño winter were omitted from the analysis. Collectively, our observations demonstrated significant coupling between adult reproduction and local recruitment in surfgrass that was interrupted by adverse growing conditions associated with the 1997-1998 El Niño.
\end{abstract}

KEY WORDS: Seagrass $\cdot$ Plant reproduction $\cdot$ Phyllospadix torreyi $\cdot$ Phenology $\cdot$ El Niño $\cdot$ Dispersal Pollen limitation

Resale or republication not permitted without written consent of the publisher

\section{INTRODUCTION}

Most studies investigating the relationship between adult fecundity and juvenile recruitment in marine systems have focused on the causes of variation in propagule dispersal and mortality (Caley et al. 1996). Much less is known about the degree to which variation in adult fecundity determines the arrival of disper- sive propagules or the recruitment of juveniles (Robertson 1991, Reed et al. 1997). This latter issue is of particular importance because widespread changes in oceanographic conditions arising from aperiodic shifts in climate such as those associated with El Niño-Southern Oscillation events have the potential to greatly influence the coupling between adult standing stocks and successful recruitment of young (Dayton \& Tegner 
1989). However, the spatial and temporal scales over which adult stocks and juvenile recruitment are coupled are unknown for most marine species (Hughes et al. 2000).

Seagrasses provide a relatively unique system to examine the links between adult fecundity and juvenile recruitment, as they are a marine taxon with flowering and fruiting characteristics typical of land plants. They occur in dense aggregations in shallow coastal habitats worldwide (den Hartog 1970, Phillips \& Menez 1988) and provide important ecological functions in the areas in which they occur (reviewed in Larkum et al. 2006). Despite their long evolutionary history, seagrass populations are now challenged with rapid environmental changes as a result of coastal human population pressures (Short \& Wyllie-Echeverria 1996, Bull et al. 2004, Ralph et al. 2006), and understanding patterns and sources of variation in adult reproduction and seedling recruitment is critically important to ongoing conservation and management efforts (Orth et al. 2000, 2006a,b, Duarte 2002).

The relatively short stature, simple architecture and shallow depths characteristic of seagrasses, combined with visible flowers, fruits and seedlings, allow for tractable demographic studies on adult reproduction and seedling establishment in seagrasses (Blanchette et al. 1999, Ackerman 2006, Orth et al. 2006a, Shelton 2008). Nonetheless, our knowledge of seed dispersal in seagrasses, a process that can potentially decouple the link between reproductive output of a local adult population and recruitment of young, is far from complete. Conventional wisdom is that the distance over which seagrass seeds freely disperse is limited to a few to $10 \mathrm{~s}$ of $\mathrm{m}$ for most species due to morphological adaptations (i.e. negative buoyancy, barbs or bristles for attachment) of seeds that promote their retention (Blanchette et al. 1999, Orth et al. 2006a). However, mature reproductive shoots of many of these species float upon becoming dislodged and they, along with the viable seeds that they contain, are capable of dispersing 10s to 100s of km (Orth et al. 2006a). Clearly, the relative importance of long-distance dispersal vs. seed retention within local populations will affect the strength of the relationship between adult reproductive output and local recruitment.

The surfgrasses Phyllospadix spp. are among the most productive seagrass systems yet studied (RamirezGarcia et al. 1998). They are unique among seagrasses in that they have specially adapted adventitious roots that enable them to grow on rocks in wave-swept areas (Cooper \& McRoy 1988, Phillips \& Menez 1988). P. torreyi is an abundant surfgrass that occurs in dense, persistent stands in the rocky intertidal and shallow subtidal zones of exposed shores along the Pacific coast of North America (Dudley 1893, Phillips 1979, Williams
1995). The species is characterized by long, slender shoots that emerge from creeping rhizomes that are solidly attached to rocky substrates by branching root hairs. Plants are dioecious perennials and both sexes produce long, branched reproductive shoots supporting sexually dimorphic spikes of flowers termed spadices. The non-fleshy fruit produced by the female contains a single seed (Dudley 1893) whose endocarp forms 2 armsF with stiff, barbed bristles that function in attachment (Gibbs 1902, Turner 1983, Blanchette et al. 1999). Upon dehiscence, the negatively buoyant fruit drifts along the bottom until the barbed arms become entangled with a host alga or a conspecific plant. Seed germination and seedling establishment typically occur at the site of the host.

Based on the morphological characteristics of the dispersive fruit of Phyllospadix torreyi, we hypothesized that dispersal distances would be short and that flowering, seed supply and seedling recruitment would be positively correlated in years with favorable growing conditions. To test this hypothesis we measured these processes at 5 sites near Santa Barbara, California, over a $5 \mathrm{yr}$ period that coincidentally encompassed one of the strongest El Niño events on record. Our objectives were to determine: (1) spatial and temporal patterns of flowering phenology, seed production, seed supply and seedling recruitment; (2) the degree of variation in seed supply explained by seed production; (3) the amount of variation in seedling recruitment explained by seed production and seed supply; and (4) the extent to which these relationships varied among sites and years.

\section{MATERIALS AND METHODS}

Study sites. We followed patterns of surfgrass flowering, seed supply and seedling recruitment at 5 sites along a $58 \mathrm{~km}$ stretch of the mainland coast of the Santa Barbara Channel. The coastline in this region is aligned in an east-west orientation and all 5 study sites are moderately exposed to west and northwest swells that are typical of winter. The Channel Islands form the southern border of the Santa Barbara Channel and protect the mainland coast from south swells, which typically occur in the summer. While sea surface temperature can vary greatly throughout the Santa Barbara Channel (Reed et al. 2000) the difference in temperature among the 5 study sites at any one point in time is typically $<1^{\circ} \mathrm{C}$ (Santa Barbara Coastal Long Term Ecological Research project, http://sbc.lternet. edu). We used sea surface temperature data from NOAA buoy 46054 in the western Santa Barbara Channel to characterize interannual variability in ocean temperature and nutrients in the study region. 
Temperature and nitrate are inversely correlated in the Santa Barbara Channel and elsewhere in California (Jackson 1977, Zimmerman \& Kremer 1984, McPheeShaw et al. 2007).

In the Santa Barbara region, Phyllospadix torreyi covers rocky benches and boulders that occur in discrete patches from the low intertidal zone into the subtidal to depths of about $4 \mathrm{~m}$ (Holbrook et al. 2000), which is typical for the genus throughout its distribution in the NE Pacific (Phillips 1979). All 5 study sites - from west to east, Alegria $\left(34^{\circ} 28^{\prime} 08^{\prime \prime} \mathrm{N}, 120^{\circ} 16^{\prime} 20^{\prime \prime} \mathrm{W}\right)$, Devereux $\left(34^{\circ} 22^{\prime} 23^{\prime}\right.$ 'N, $\left.119^{\circ} 52^{\prime} 40^{\prime \prime} \mathrm{W}\right)$, Hendry's (34 $24^{\circ} 12^{\prime \prime} \mathrm{N}$, $\left.119^{\circ} 44^{\prime} 51^{\prime \prime} \mathrm{W}\right)$, Mohawk (342 23' 38'"' N, $119^{\circ} 43^{\prime} 45^{\prime \prime} \mathrm{W}$ ) and Shoreline $\left(34^{\circ} 23^{\prime} 45^{\prime \prime} \mathrm{N}, 119^{\circ} 42^{\prime} 26^{\prime \prime} \mathrm{W}\right)-\mathrm{con}-$ tained extensive (100s of $\mathrm{m}^{2}$ ) beds of $P$. torreyi, and all surfgrass data were collected within a $50 \times 50 \mathrm{~m}$ area at each site. Studies at Alegria, Devereux, Hendry's and Shoreline were conducted in the low intertidal zone ( 0 to $-0.4 \mathrm{~m}$ mean lower low water, MLLW). Data from Mohawk were collected in the shallow subtidal ( -2 to -4 m MLLW) where a companion study on seedling restoration was being conducted (Bull et al. 2004).

Density and phenology of flowers. Data on the density and reproductive state of flowers were collected monthly from June 1996 to July 1997 and from June 1998 to February 2000. At each site we counted the number of male and female spadices in 10 permanent $1 \mathrm{~m}^{2}$ quadrats interspersed among surfgrass-covered rocky substrates distributed throughout the $50 \times 50 \mathrm{~m}$ sampling area. Distances between adjacent quadrats varied with the distribution of rock, but in all cases were at least $4 \mathrm{~m}$. We examined among-site differences in the timing of female floral development by classifying the reproductive condition of each female spadix into 1 of 5 flowering states according to the majority of flowers in the spadix: (1) bud (developing spadix with no visible flowers), (2) flower (unpollinated flower with stigmas extended), (3) fruit (fertilized ovules with developing seeds), (4) aborted (small abnormal fruit showing signs of atrophy) or (5) dehisced (senescent spadix with released fruit). The effects of site and year on the proportion of female spadices in the aborted and dehisced states were tested using fixed 2-factor ANOVAs.

To determine whether the spadix was an appropriate unit for assessing variation in the density and phenology of female flowers, we counted the number and recorded the reproductive state of each flower in the spadices of 10 female flowering shoots haphazardly collected from each site on 5 dates in 1998 that spanned the flowering season (July to November). We used separate single factor ANOVAs to test whether the number of flowers per spadix, and the proportion of flowers within a spadix that were in the same reproductive state, varied among sites using sampling date as replicates.
Seed supply. We deployed traps in the surfgrass zone at the 5 sites from January 1996 through February 2000 to assess patterns of abundance of dehisced fruits (hereafter referred to as seeds following common usage for Phyllospadix). Each trap consisted of 2 pieces of $30 \times 30 \mathrm{~cm}$ polyester mesh fastened together at their centers with a nylon cable tie bolted to the substrate along the permanent transects at each of the 5 study sites ( $\mathrm{N}=10$ traps per site). The 2 pieces of fabric had different mesh sizes to accommodate the slight variability in seed size: $1.7 \mathrm{~mm}$ diameter polyester stretch mesh with round openings (polyester netting \#9622, Research Nets) and $1.0 \mathrm{~mm}$ diameter mesh with square openings (nylon netting Delta 1004A, Memphis Net and Twine). The fabric diameter of the mesh and overall size of the trap were similar to branched algae known to facilitate seed attachment, and laboratory tests in an oscillating flow tank revealed that seeds attached to the mesh traps at rates similar to those recorded for many common host algae (Blanchette et al. 1999). Traps were retrieved after 1 mo in the field and empty traps were re-deployed at the same locations. Using this approach we obtained estimates of the number of seeds entrapped by a typical host alga (as represented by each trap) at 10 fixed locations per site each month over a continuous 50 mo period. We used a single factor ANOVA to test overall differences in seed supply among sites using sampling dates as replicates and the mean number of seeds caught per trap per day as the response variable.

Seedling establishment. Because surfgrass seedlings recruit almost exclusively to branching algae as well as the rhizomes and senescent leaves of adult surfgrass (Blanchette et al. 1999), we restricted our surveys of seedlings to areas where these host species were abundant. We estimated the densities of recently germinated seedlings at each site by searching for them in $30 \times 30 \mathrm{~cm}$ quadrats. To maximize sampling interspersion and minimize sampling bias we located areas where the dominant vegetation cover consisted of species known to facilitate the recruitment of surfgrass seedlings (e.g. the branching red algae Bossiella orbigniana, Chondracanthus canaliculatus, Corallina chilensis, Corallina vancouveriensis, Endocladia muricata, Gelidium purpurascens and senescent surfgrass; Blanchette et al. 1999) and haphazardly tossed the quadrats in the patches containing the desired vegetation. Care was taken to sample the different species of the facilitator vegetation according to their relative abundance at each site in order to adequately characterize seedling density at each site.

Data on annual patterns of seedling density were collected from 1997 to 2000 at all 5 sites during winter after the flowering season, when seedlings are most abundant (Blanchette et al. 1999). On each sampling 
date, the percent cover of each species of algae and the rhizomes and senescent leaves of surfgrass were estimated visually in each quadrat and the number of seedlings was counted. These data on seedling density were standardized to the combined coverage of all host species within each quadrat and used in simple linear regressions to examine various relationships among the abundances of flowers, seeds and seedlings.

\section{RESULTS}

Similar to previous reports (e.g. Dudley 1893, Williams 1995), we observed a strong female bias in flowering at our study sites (Fig. 1). Male flowers were common only at one site (Devereux) on one occasion (late August 1996), when they accounted for

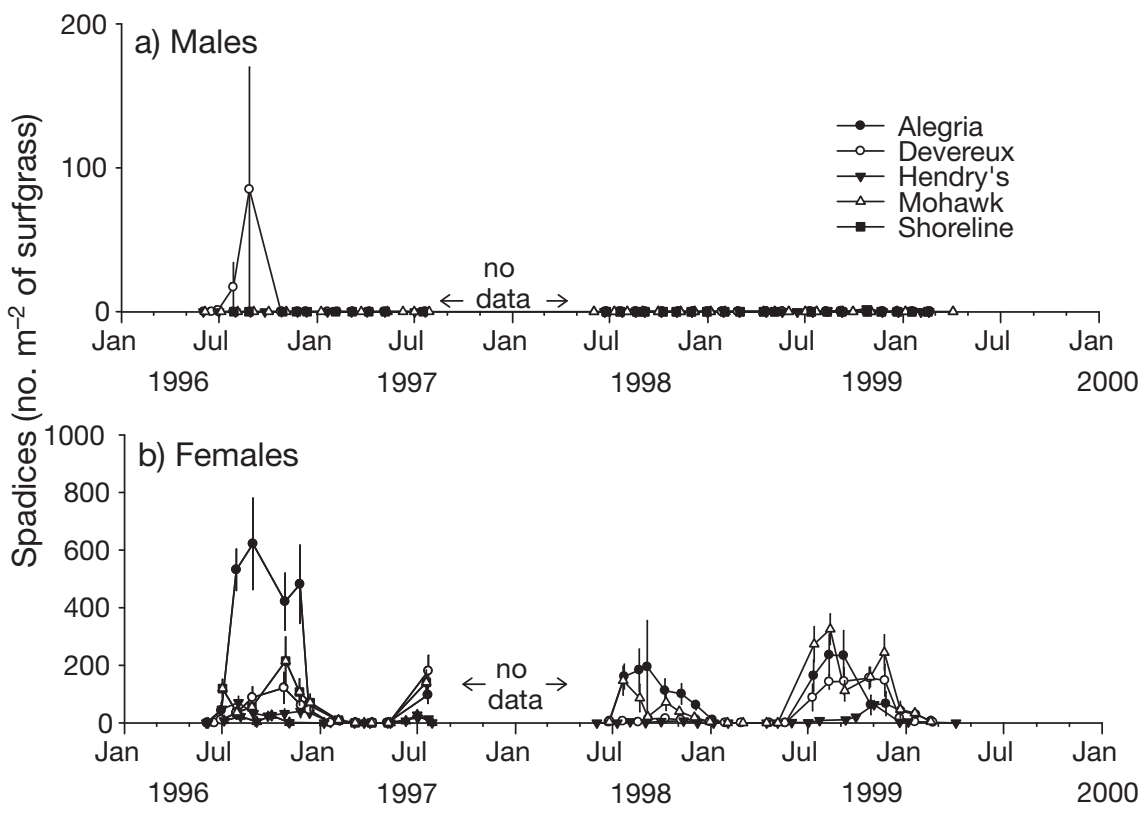

Fig. 1. Phyllospadix torreyi. Density of (a) male and (b) female spadices at the 5 study sites. Data are monthly means $( \pm \mathrm{SE})$ standardized to the area occupied by surfgrass

$49 \%$ of all spadices observed at the site (Fig. 1a). Male flowers were rare or absent at all other times during our study (Fig. 1a). In fact, male reproductive shoots were never observed in study plots at Shoreline or Mohawk and only one male reproductive shoot was ever observed at Alegria.

Unlike males, flowering by females was common in study plots at all of our sites (Fig. 1b). We observed the vast majority of female flowers between early summer and early winter during each of the 3 years studied. In general, female spadices first appeared in June, reached peak abundance in September and largely disappeared by January, with a few persisting until February at some sites in some years. The density of female spadices differed significantly among sites $\left(F_{4,186}=10.15, \mathrm{p}<0.0001\right)$, as the overall abundance of flowers was highest at Alegria, lowest at Mohawk (the lone subtidal site) and intermediate at Devereux, Hendry's and Shoreline (Ryan-Einot-Gabriel-Welsch multiple-range test, $\alpha=0.05$ ).

The number of flowers per female spadix was similar among sites $\left(F_{4,22}=1.12, \mathrm{p}=0.3709\right)$ with an overall average of approximately 10 (Fig. 2a). Importantly, the percentage of flowers within a given female spadix that were in the same reproductive state was similarly high (i.e. $>90 \%)$ at all sites $\left(F_{4,22}=0.38, p=0.8177\right)$ (Fig. $\left.2 b\right)$. Taken together, these results show that our data on spadix abundance and condition provided an accurate estimate of the density and reproductive state of female flowers at our sites during the period of study.

Flowering phenology tended to vary more among years than among sites (Fig. 3). In 1996 the majority of

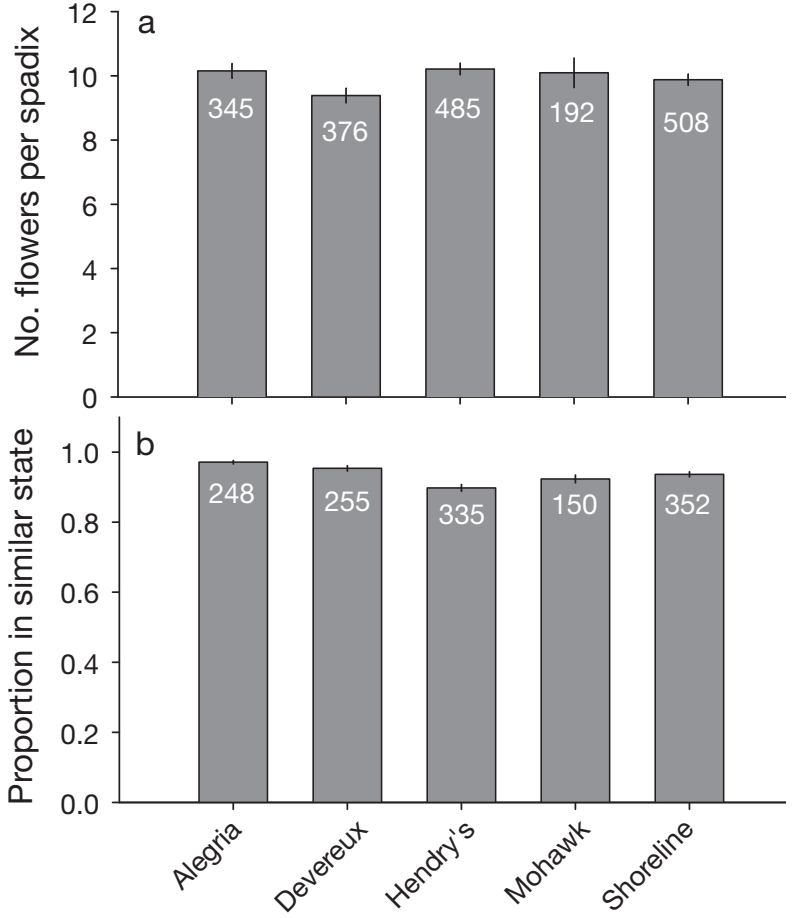

Fig. 2. Phyllospadix torreyi. (a) Number of flowers per female spadix and (b) proportion of flowers within a spadix that were in the same reproductive state at the 5 study sites. Data are means (SE) averaged over 5 sampling dates during the 1998 flowering season. Numbers within each bar are the number of spadices sampled at each site

female spadices were in a state of dehiscence by October at 4 of the 5 sites, whereas in 1999 dehiscence was mostly delayed at all sites until November and December (Fig. 3). The proportion of spadices in a dehisced 


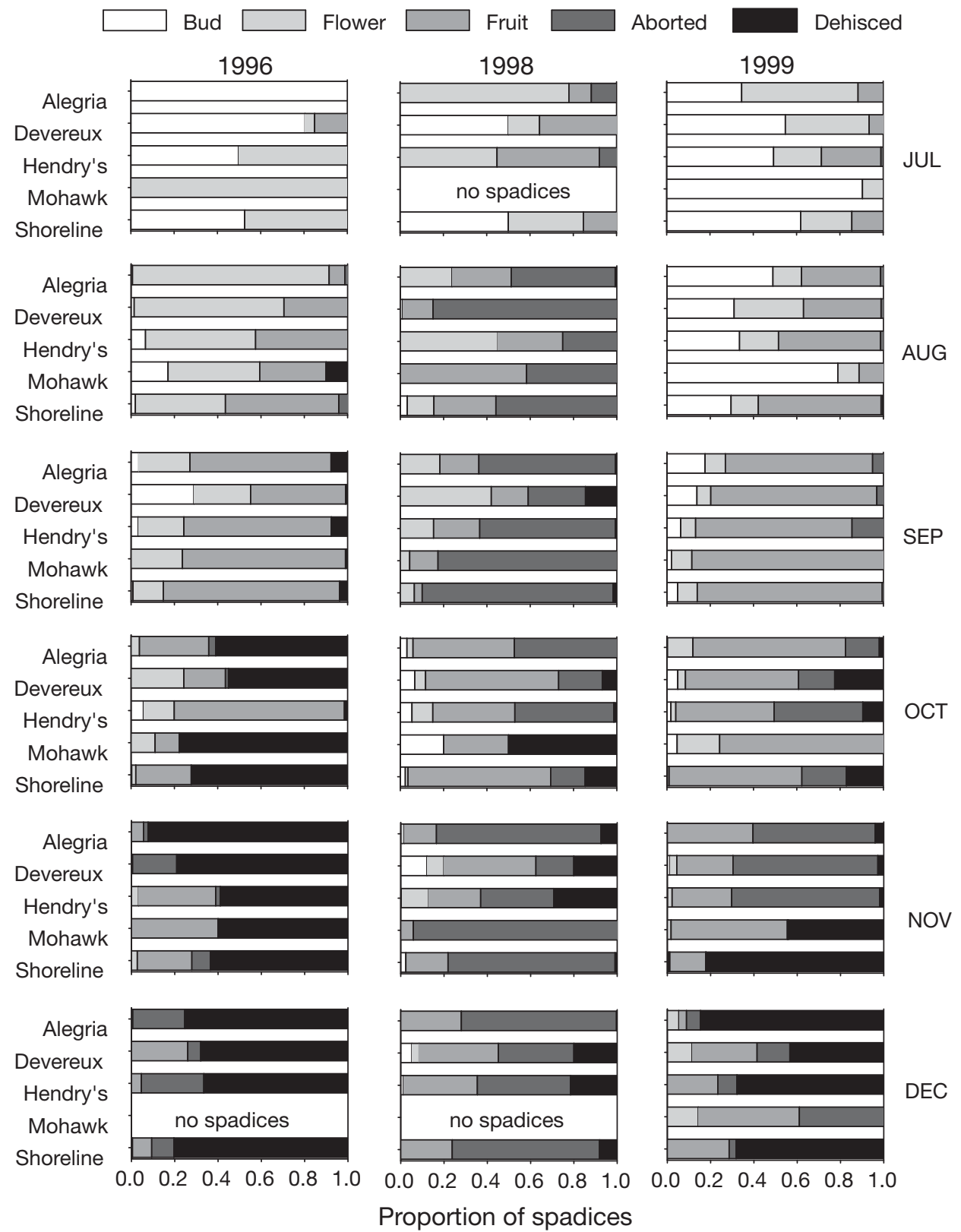

Fig. 3. Phyllospadix torreyi. Reproductive phenology of female surfgrass at the 5 study sites during the flowering seasons of 1996, 1998 and 1999. Data are based on all spadices present in fixed quadrats at the time of sampling state was generally similar among sites $\left(F_{4,59}=0.15\right.$, $\mathrm{p}=0.9615)$ but differed consistently among years (year: $F_{2,59}=8.18, \mathrm{p}=0.0007$; site $\times$ year interaction: $F_{8,59}=0.28, p=0.9716$ ) (Fig. 4a,b). The most striking difference occurred in 1998, when most fruits failed to mature and dehisce and high levels of aborted fruits were observed. On average, rates of abortion were 6 times higher in 1998 compared to 1996, and nearly twice as high as in $1999\left(F_{2,59}=6.14, \mathrm{p}=0.0038\right)$ (Fig. 4c). That the prevalence of aborted fruits did not differ significantly among sites $\left(F_{4,59}=0.45, \mathrm{p}=0.7701\right.$, Fig. 4d) irrespective of year (site $\times$ year interaction: $F_{8,59}=0.51, \mathrm{p}=0.841$ ) suggests that regional changes in environmental conditions led to the observed inter- annual differences in flowering phenology and fruit production. Sea surface temperature data from the west Santa Barbara Channel support this contention, as temperatures were as much as 2 to $4^{\circ} \mathrm{C}$ higher in 1997 and 1998 than the 13 yr mean recorded between 1994 and 2006 (Fig. 5).

Patterns of seed supply were generally similar to those observed for flowers with some notable differences. As observed for the density of female spadices, the mean number of seeds caught per trap peaked in autumn (September to December) and differed significantly among sites $\left(F_{4,263}=5.79, \mathrm{p}=0.0002\right)$ (Fig. 6). Overall, seed supply was highest at Alegria, lowest at Mohawk and intermediate at Devereux, Hendry's and 

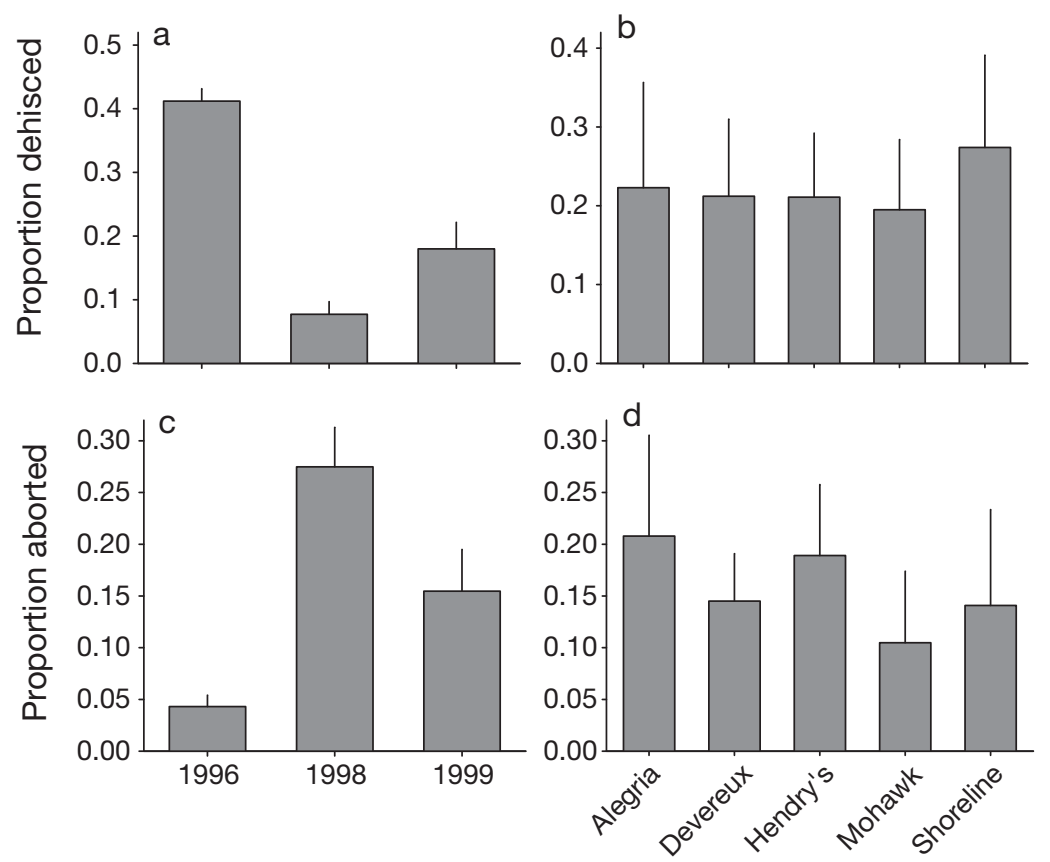

Fig. 4. Phyllospadix torreyi. Mean proportion of spadices with $(\mathrm{a}, \mathrm{b})$ dehisced fruits and (c,d) aborted fruits during August through December. Values in (a) and $(\mathrm{c})$ are means $( \pm \mathrm{SE})$ averaged over all sites $(\mathrm{n}=5)$; values in $(\mathrm{b})$ and $(\mathrm{d})$ are means averaged over all years $(n=3)$

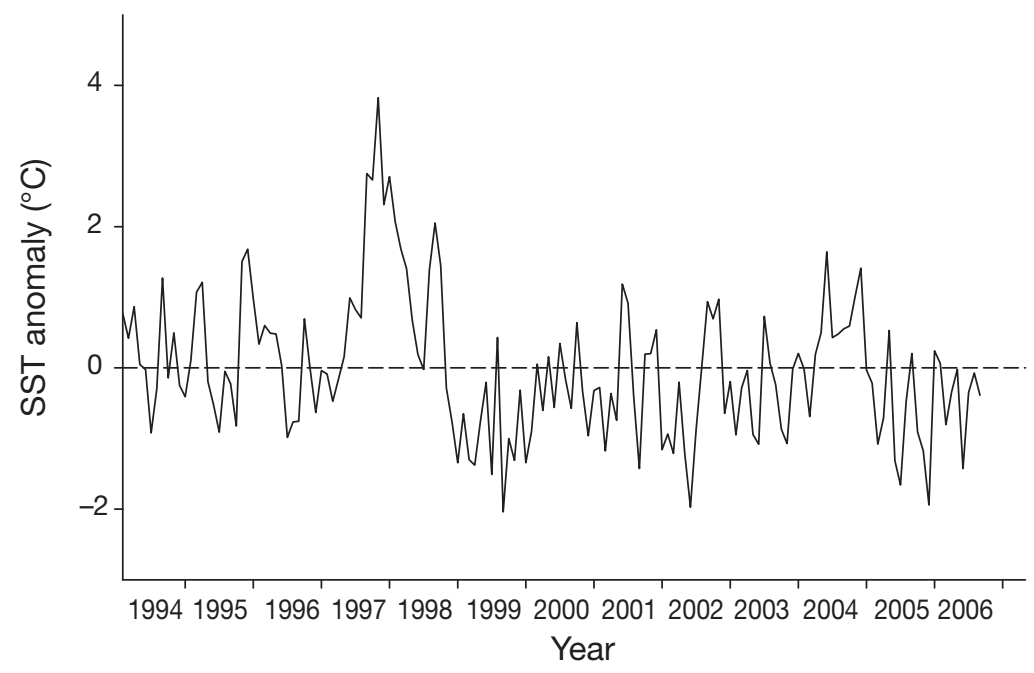

Fig. 5. Monthly sea surface temperature (SST) anomalies in the Santa Barbara Channel. Data are from NOAA buoy 46054, and anomalies were calculated from mean monthly temperature data collected from January 1994 through December 2006

Shoreline (Ryan-Einot-Gabriel-Welsch multiple-range test, $\alpha=0.05)$. Very few seeds were caught at any site during the autumn of 1998, which is when fruits failed to develop in most spadices (Figs. $3 \& 4$ ). Interestingly, noticeable numbers of seeds were caught in traps placed at Alegria, Hendry's and Shoreline during April 1997 with lesser (but nonetheless non-zero) numbers caught during other months of the spring (Fig. 6) when female flowers were not observed (Fig. 1). The mean number of seeds caught per trap during a given month was positively related to the density of female spadices at that site at the beginning of the month, but the relationship was highly variable and only explained $\sim 7 \%$ of the variation in the number of seeds caught per trap $\left(r^{2}=0.072, p=0.0018\right)$ (Fig. 7a). The density of dehisced female spadices at a site was a better predictor of seed supply, as it explained nearly $41 \%$ of the variation in the mean number of seeds caught per trap $\left(\mathrm{r}^{2}=0.408, \mathrm{p}<0.0001\right)$ (Fig. 7b). This relationship was influenced greatly by 2 sampling dates at Alegria in the autumn of 1996 when the density of female spadices was very high $\left(\mathrm{r}^{2}=0.15\right.$ when these 2 points are omitted from the regression). Furthermore, there were many instances when substantial numbers of seeds were caught in traps where the local density of female spadices was low, irrespective of their reproductive state.

The winter density of seedlings varied substantially among sites and years (Fig. 8). Most notable was the absence of seedlings at all sites in the winter of 1999 following the widespread failure of fruiting in fall 1998 (see Fig. 3). Also noteworthy was the fact that seedlings were never observed at Mohawk during the entire study. Overall, the summertime densities of female spadices at a site explained more than $60 \%$ of the variation in the density of seedlings that recruited to the site in the following winter $\left(\mathrm{r}^{2}=0.611, \mathrm{p}<\right.$ 0.0001) (Fig. 9a). When examined over all 4 years, there was no relationship between the total number of seeds caught per trap during the flowering season (July to December) and the density of seedlings during the following winter (January to February of the subsequent year; $\mathrm{r}^{2}=$ 0.076, p = 0.239) (Fig. 9b). This resulted primarily from the 1997 flowering season, when seedling density at all sites in winter 1998 was low despite wide variation in the number of seeds caught per trap during fall 1997. The relationship between seedling density and the number of seeds caught per trap became highly significant $\left(\mathrm{r}^{2}=\right.$ $0.577, \mathrm{p}<0.0001$ ) when data from the 1997 flowering season were omitted from the regression analysis, suggesting that seed supply was a good predictor of seedling recruitment in 3 of the 4 years studied. 


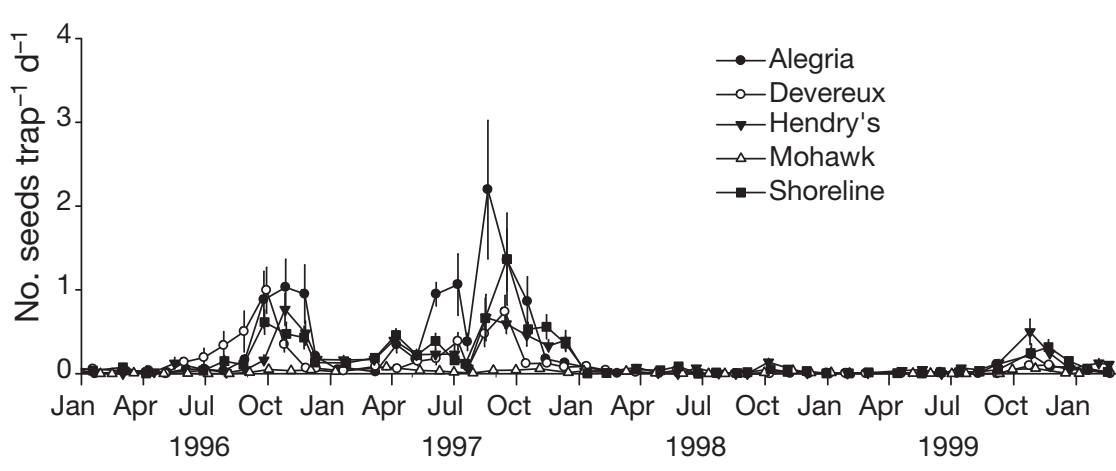

Fig. 6. Phyllospadix torreyi. Monthly values of the number of seeds caught per trap per day at the 5 study sites. Data are means $( \pm$ SE) over 10 traps per site

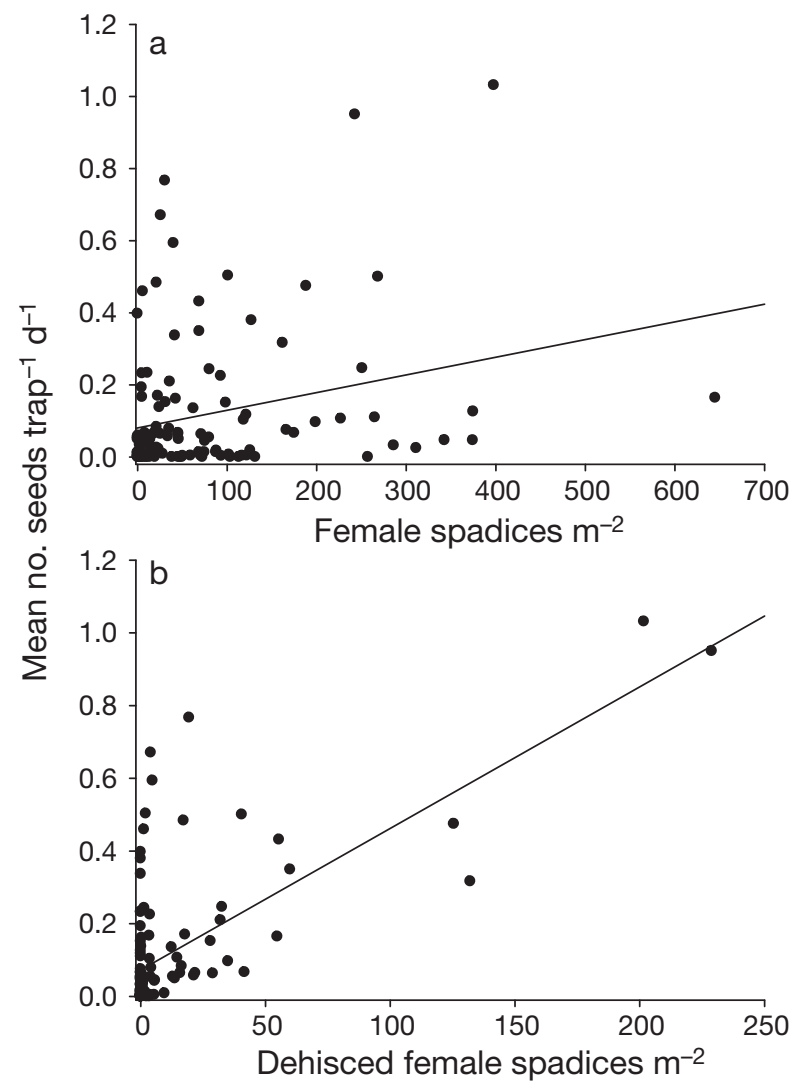

Fig. 7. Phyllospadix torreyi. Relationship between the mean number of seeds caught per trap and the density of female spadices (a) in all states of reproduction and (b) in a state of dehiscence at the time traps were deployed. Data represent monthly values. Because the number of days during a sampling period varied, seed trap data were standardized to the number of seeds caught per day

\section{DISCUSSION}

We found that female flower density, seed supply and seedling recruitment in surfgrass varied considerably in time and space as did the dependency of these variables on one another. Previous work has shown that the density of attached seeds and seedlings of the genus Phyllospadix were strongly dependent on the abundance and morphology of the host algae to which they attached (Turner 1983, Blanchette et al. 1999). In the present study we accounted for this variation in host algae by using standardized traps to quantify seed supply and by normalizing seedling recruitment to the abundance of algae known to facilitate their attachment. In doing so, we found that the number of seeds caught per trap and the density of seedlings at a given site were dependent to varying degrees on the density of female flowers at that site. One notable exception was the paucity of trapped seeds and the complete absence of seedlings in our subtidal surveys at Mohawk despite an abundance of flowers. The specific reasons for this absence are not known, but may reflect lower survivorship of seedlings there compared to the other 4 intertidal sites. Evidence for this comes from Bull et al. (2004), who found the survivorship of transplanted seedlings to be lower in the subtidal at Mohawk compared to a nearby intertidal site.

Our observed departures from positive associations among surfgrass flowers, seeds and seedlings likely reflected changes in environmental conditions between summer/fall, when pollination occurs and fruits are provisioned, and the following winter, when seedlings first appear. Such was found to be the case for 4 out of 5 species of oaks in central coastal California, where variation in weather during floral and seed development explained up to $78 \%$ of the variation in acorn crop size (Koenig et al. 1996). In the present study, the absence of surfgrass seedlings in winter 1999 can be traced to the

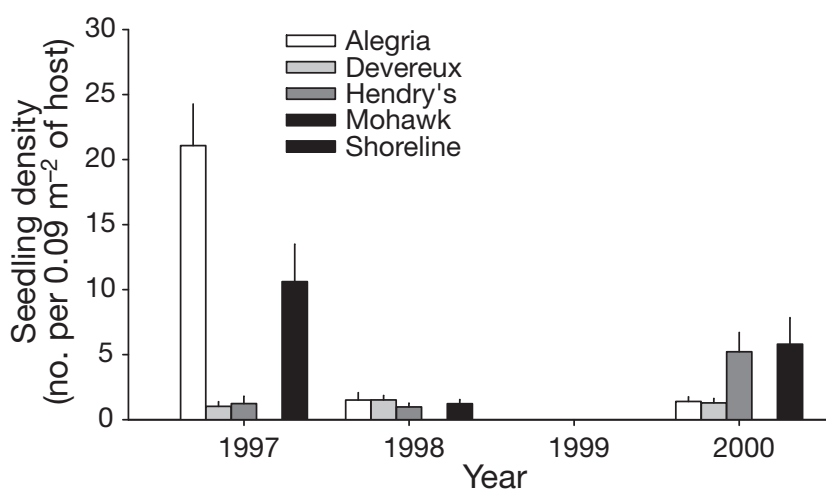

Fig. 8. Phyllospadix torreyi. Interannual variation in the densities of surfgrass seedlings during winter at the 5 study sites. Values are means (SE) standardized to the percent cover of host vegetation known to facilitate seed attachment 


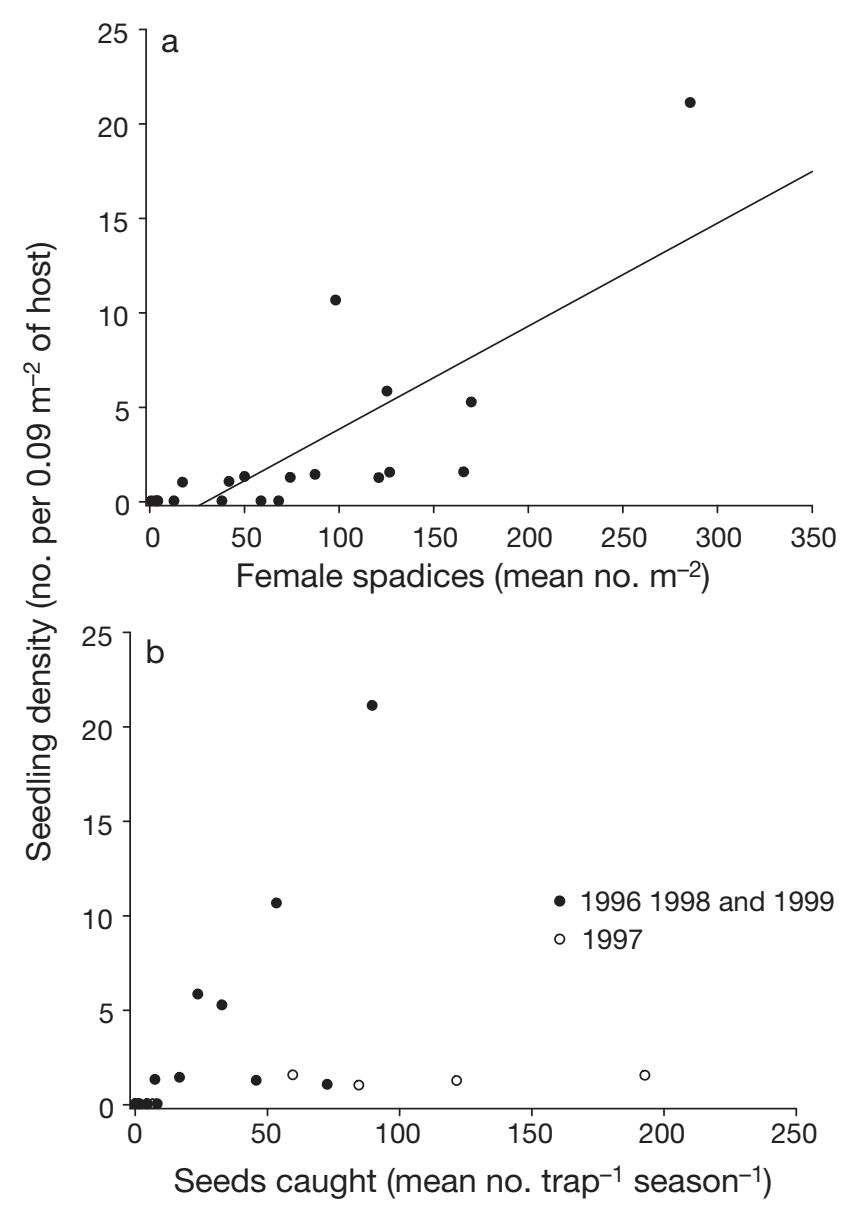

Fig. 9. Phyllospadix torreyi. The relationship between the density of seedlings in winter (standardized to host abundance) and (a) the mean density of female spadices the preceding summer and (b) the mean number of seeds caught per trap over the entire flowering season (the preceding July through December)

pervasive failure of fruits to mature in fall 1998 when high levels of aborted fruits were observed. This coincided with one of the strongest El Niño events on record (Wolter \& Timlin 1998). Anomalous ocean conditions characterized by high temperature, low salinity, low nutrients and large waves were reported in 1997 and 1998 for the entire west coast of North America, including the Santa Barbara area (Allan \& Komar 2002, Chavez et al. 2002a, our Fig. 5). These conditions have been linked to observed large declines in phytoplankton and macroalgal biomass and overall ocean productivity during that period (Chavez et al. 2002b, Shipe et al. 2002, Edwards 2004), and likely had similar adverse effects on the maturation of fruits and the survival of seedlings in surfgrass.

We do not know which specific environmental factors led to the reproductive failures that we observed in surfgrass during the 1997-1998 El Niño. In addition to the anomalous ocean conditions noted above, abnormal atmospheric conditions (e.g. increased frequency of low clouds and precipitation) were reported in California during 1998 and were linked to changes in air temperature, humidity and radiation (McPhaden 1999, Cess et al. 2001). Such changes could also have influenced surfgrass reproduction, seed provisioning and seedling survival, especially in intertidal habitats during afternoon low tides when surfgrass is most susceptible to inclement weather conditions. Interestingly, Knapp et al. (2001) observed a similar near complete failure in acorn production by blue oaks in 1998 at an inland site in central California. Although these authors did not reference El Niño, they attributed the lack of acorn production to anomalous multi-day dry spells that occurred during the pollination period in spring of 1998.

A somewhat surprising result from the present study was the occasional deposition of seeds during spring, when female flowers were locally rare or absent. While we did not witness flowering during spring at our sites, its occurrence has been reported in both sexes throughout the year elsewhere, albeit at much lower levels (Stewart 1989, Williams 1995). The dispersal of seeds produced from springtime flowering at neighboring sites may have been sufficient to explain the aseasonal patterns in seed supply that we observed. Mechanisms of extended dispersal have not been examined in surfgrass, but likely involve the transport of detached reproductive shoots and/or spadices. Surfgrass seeds germinate readily upon dehiscence (Reed et al. 1998), and the stiff, inwardly pointed barbs on the winged fruit cause them to readily attach and firmly adhere to a number of commonly occurring species of marine vegetation (Blanchette et al. 1999). These traits make it seem unlikely that extended seed dispersal in surfgrass routinely occurs via the transport of settled seeds that become dislodged and re-establish at neighboring sites. A more feasible explanation for our observations of seed deposition in the absence of locally abundant flowers is the transport of intact reproductive shoots and spadices that become dislodged and set adrift.

Numerous studies have found that seed production in many species of wind pollinated trees is often greatest in years when the local production of male flowers is high (Knapp et al. 2001 and references therein). These empirical observations, coupled with genetic analyses and theoretical models of pollen movement (Satake \& Iwasa 2002, Sork et al. 2002), have led to suggestions that pollen limitation may play a much greater role in causing highly variable seed production in wind-pollinated trees (Koenig \& Ashley 2003). Similar arguments may pertain to submarine pollination in seagrasses (reviewed in Ackerman 2006) and surfgrass 
in particular (Shelton 2008). Nonetheless, it is unlikely that pollen limitation arising from variation in the local production of male flowers contributed to the high variability that we observed in the production of surfgrass seeds and seedlings. Male flowers were rare at all of our sites in all years except at Devereux in 1996, yet the abundance of seeds and seedlings varied substantially among sites and years. Our observations of high seed production at sites where males were rare or absent suggest that pollen dispersal in surfgrass may routinely occur over distances greater than the scale of our study sites (i.e. $>50 \mathrm{~m}$ ), which would be substantially greater than that reported by Ruckelshaus (1996) for the seagrass Zostera marina. Much like seed dispersal, pollination in seagrasses is not necessarily confined to securely attached plants, as drifting reproductive shoots could similarly extend pollination distances in surfgrass. Additional studies are needed to determine the importance of this mechanism in accounting for the puzzling pattern of high seed set by surfgrass in the near or complete absence of nearby flowering male plants.

In summary, our results suggest that the production of seeds and seedlings in Phyllospadix torreyi is dependent on the local density of female flowers during years when growing conditions are favorable. Anomalous weather conditions during the periods of seed provisioning and seedling recruitment (such as those that occurred during the 1998 El Niño) can adversely affect seed production and seedling survival, and severely disrupt the coupling between adult reproduction and juvenile recruitment. The common occurrence of an abundant supply of seeds at sites when local seed production was relatively low suggests that seed dispersal in $P$. torreyi is not restricted to the immediate vicinity of the parental source. Such extended dispersal, which is known to occur in other species of seagrass (Orth et al. 2006a), likely acts to weaken the correlation between adult reproduction and local recruitment in surfgrass, which could reduce its susceptibility to some of the adverse effects of population fragmentation caused by a variety of human activities and natural disturbances (Koenig \& Ashley 2003). A more comprehensive understanding of the patterns and mechanisms of pollen and seed dispersal are needed to determine the spatial scales of fragmentation that lead to reduced reproductive success in surfgrass populations.

Acknowledgements. We thank M. Anghera for his help and encouragement in all phases of this work. We also thank the many individuals who assisted us in the field, especially S. Bull, C. Galst and E. Solomon. The research was supported by the Coastal Toxicology Component of the University of California Toxic Substances Research and Training Program, the County of Santa Barbara, California, the Minerals Man- agement Service of the US Department of the Interior (MMS Agreement No. 14-35-00011-30758) and the National Science Foundation's Long-Term Ecological Research program.

\section{LITERATURE CITED}

Ackerman JD (2006) Sexual reproduction of seagrasses: pollination in the marine context. In: Larkum AWD, Orth RJ, Duarte CM (eds) Seagrasses: biology, ecology, and conservation. Springer, Dordrecht, p 89-109

Allan JC, Komar PD (2002) Extreme storms on the Pacific Northwest coast during the 1997-98 El Niño and 1998-99 La Niña. J Coast Res 18:175-193

Blanchette CA, Worcester SE, Reed DC, Holbrook SJ (1999) Algal morphology, flow, and spatially variable recruitment of surfgrass Phyllospadix torreyi. Mar Ecol Prog Ser 184: $119-128$

Bull JS, Reed DC, Holbrook SJ (2004) An experimental evaluation of different methods of restoring Phyllospadix torreyi (surfgrass). Restor Ecol 12:70-79

Caley MJ, Carr MH, Hixon MA, Hughes TP, Jones GP, Menge BA (1996) Recruitment and the local dynamics of open marine populations. Annu Rev Ecol Syst 27:477-500

Cess RT, Zhang M, Wielicki BA, Young DF, Zhou X, Nikitenko Y (2001) The influence of the 1998 El Niño upon cloud-radiative forcing over the Pacific warm pool. J Clim 14:2129-2137

Chavez FP, Collins CA, Huyer A, Macka DL (2002a) El Niño along the west coast of North America. Prog Oceanogr $54: 1-5$

Chavez FP, Pennington JT, Castro CG, Ryan JP and others (2002b) Biological and chemical consequences of the 1997-1998 El Niño in central California waters. Prog Oceanogr 54:205-232

> Cooper LW, McRoy CP (1988) Anatomical adaptations to rocky substrates and surf exposure by the seagrass genus Phyllospadix. Aquat Bot 32:365-381

Dayton PK, Tegner MJ (1989) Bottoms beneath troubled waters: benthic impacts of the 1982-1984 El Niño in the temperate zone. In: Glynn PW (ed) Global ecological consequences of the 1982-83 El Niño-Southern Oscillation. Elsevier Oceanography Series No. 52, Amsterdam, p 433-472

den Hartog C (1970) The sea-grasses of the world. NorthHolland, Amsterdam

Duarte CM (2002) The future of seagrass meadows. Environ Conserv 29:192-206

Dudley WR (1893) The genus Phyllospadix. Wilder QuarterCentury Book, Comstock, Ithaca, NY, p 403-420

Edwards MS (2004) Estimating scale-dependency in disturbance impacts: El Niños and giant kelp forests in the northeast Pacific. Oecologia 138:436-447

> Gibbs RE (1902) Phyllospadix as a beach builder. Am Nat 36: 101-109

> Holbrook SJ, Reed DC, Hansen K, Blanchette CA (2000) Spatial and temporal patterns of predation on seeds of surfgrass Phyllospadix torreyi. Mar Biol 136:739-747

Hughes TP, Baird AH, Dinsdale EA, Moltschaniwskyj NA, Pratchett MS, Tanner JE, Willis BL (2000) Supply-side ecology works both ways: the link between benthic adults, fecundity, and larval recruits. Ecology 81:2241-2249

Jackson GA (1977) Nutrients and production of giant kelp, Macrocystis pyrifera, off southern California. Limnol Oceanogr 22:979-995

> Knapp EE, Goedde MA, Rice KJ (2001) Pollen-limited reproduction in blue oak: implications for wind pollination in 
fragmented populations. Oecologia 128:48-55

Koenig WD, Ashley MV (2003) Is pollen limited? The answer is blowin' in the wind. Trends Ecol Evol 18:157-159

Koenig WD, Knops JMH, Carmen WJ, Stanback MT, Mumme RL (1996) Acorn production by oaks in central coastal California: influence of weather at three levels. Can J For Res 26:1677-1683

Larkum AWD, Orth RJ, Duarte CM (2006) Seagrasses: biology, ecology, and conservation. Springer, Dordrecht

McPhaden MJ (1999) Genesis and evolution of the 1997-98 El Niño. Science 283:950-954

McPhee-Shaw EE, Siegel DA, Washburn L, Brzezinski MA, Jones JL, Leydecker A, Melack J (2007) Mechanisms for nutrient delivery to the inner shelf: observations from the Santa Barbara Channel. Limnol Oceanogr 52:1748-1766

> Orth RJ, Harwell MC, Bailey EM, Bartholomew A and others (2000) A review of issues in seagrass seed dormancy and germination: implications for conservation and restoration. Mar Ecol Prog Ser 200:277-288

Orth RJ, Harwell M, Inglis G (2006a) Ecology of seagrass seeds and seagrass dispersal processes. In: Larkum AWD, Orth RJ, Duarte CM (eds) Seagrasses: biology, ecology, and conservation. Springer, Dordrecht, p 111-133

Orth RJ, Carruthers TJB, Dennison WC, Duarte CM and others (2006b) A global crisis for seagrass ecosystems. Bioscience 56:987-996

Phillips RC (1979) Ecological notes on Phyllospadix (Potamogetonaceae) in the northeast Pacific. Aquat Bot 6:159-170

Phillips RC, Menez EG (1988) Seagrasses. Smithsonian Institution Press, Washington, DC

Ralph PJ, Tomasko D, Moore K, Seddon S, Macinnis-Ng CMO (2006) Human impacts on seagrasses: eutrophication, sedimentation and contamination. In: Larkum AWD, Orth RJ, Duarte CM (eds) Seagrasses: biology, ecology, and conservation. Springer, Dordrecht, p 567-593

Ramirez-Garcia P, Lot A, Duarte CM, Terrados J, Agawin NSR (1998) Bathymetric distribution, biomass and growth dynamics of intertidal Phyllospadix scouleri and Phyllospadix torreyi in Baja California (Mexico). Mar Ecol Prog Ser 173:13-23

Reed DC, Anderson TW, Ebeling AW, Anghera M (1997) The role of reproductive synchrony in the colonization potential of kelp. Ecology 78:2443-2457

Reed DC, Holbrook SJ, Solomon E, Anghera M (1998) Studies

Editorial responsibility: Kenneth Heck,

Dauphin Island, Alabama, USA on germination and root development in the surfgrass Phyllospadix torreyi: implications for habitat restoration. Aquat Bot 62:71-80

Reed DC, Raimondi PT, Carr MH, Goldwasser L (2000) The role of dispersal and disturbance in determining spatial heterogeneity in sedentary organisms. Ecology 81:2011-2026

Robertson DR (1991) The role of adult biology in the timing of spawning of tropical reef fishes. In: Sale PF (ed) The ecology of fishes on coral reefs. Academic Press, San Diego, CA, p 356-386

Ruckelshaus MH (1996) Estimation of genetic neighborhood parameters from pollen and seed dispersal in the marine angiosperm Zostera marina L. Ecology 50:856-864

Satake A, Iwasa Y (2002) Spatially limited pollen exchange and a long-range synchronization of trees. Ecology 83: 993-1005

Shelton AO (2008) Skewed sex ratios, pollen limitation, and reproductive failure in the dioecious seagrass Phyllospadix. Ecology 89:3020-3029

Shipe RF, Passow U, Brzezinski MA, Graham WM, Pak DK, Siegel DA, Alldredge AL (2002) Effects of the 1997-98 El Niño on seasonal variations in suspended and sinking particles in the Santa Barbara Basin. Prog Oceanogr 54: $105-127$

Short FT, Wyllie-Echeverria S (1996) Natural and humaninduced disturbance of seagrasses. Environ Conserv 23: $17-27$

Sork VL, Davis FW, Smouse PE, Apsit VJ, Dyer RJ, Fernandez-M JF, Kuhn B (2002) Pollen movement in declining populations of California Valley oak, Quercus lobata: Where have all the fathers gone? Mol Ecol 11:1657-1668

Stewart JG (1989) Maintenance of a balanced and shifting boundary between the seagrass Phyllospadix and algal turf. Aquat Bot 33:223-241

Turner T (1983) Facilitation as a successional mechanism in a rocky intertidal community. Am Nat 121:729-738

Williams SL (1995) Surfgrass (Phyllospadix torreyi) reproduction: reproductive phenology, resource allocation, and male rarity. Ecology 76:1953-1970

Wolter K, Timlin MS (1998) Measuring the strength of ENSO events: How does 1997/98 rank? Weather 53:315-324

Zimmerman RC, Kremer JN (1984) Episodic nutrient supply to a kelp forest ecosystem in southern California. J Mar Res 42:591-604

Submitted: November 24, 2008; Accepted: March 27, 2009

Proofs received from author(s): May 18, 2009 